\title{
Serum Profile of Thyroid Hormones from Birth to Puberty in Buffalo Calves and Heifers
}

\author{
S.D. Ingole*, B.T. Deshmukh, A.S. Nagvekar and S.V. Bharucha
}

Department of Veterinary Physiology, Bombay Veterinary College, Parel, Mumbai - 400 012, India

\begin{abstract}
Growth is outcome of interactions among several factors, where thyroid hormones play a key role in coordination of these factors and the information of thyroid hormones in relation to growth in buffalo calves and heifers is not adequate. Thus the study was conducted on Murrah female buffalo calves and heifers, varying in age from newborn to 30 months. The study investigated the serum thyroid patterns in female Murrah buffalo calves and heifers from birth to puberty. The thyroid stimulating hormone concentration did not differ and remained almost the same from birth to $4-6$ months. The thyroid stimulating hormone then gradually increased and reached a highest value at $24-30$ months. The concentration recorded at $21-24$ months and $24-30$ month i.e. at the age of attaining the puberty, was about $3-4$ times higher than recorded at birth. The $T_{3}$ concentration recorded at $0-7$ days of age was significantly higher than recorded for other age groups, except at $18-21$ months, $21-24$ months and $24-30$ months. The $T_{3}$ concentration did not exhibit specific trend during the ages 16 days -1 month to $15-18$ months. The highest $\mathrm{T}_{4}$ concentration was recorded in $0-7$ days old buffalo calves. The concentration decreased to lower value at $1-2$ months. The $T_{4}$ concentration from $2-4$ months of age increased significantly and the values remained almost similar with minor fluctuations upto $24-30$ months. The $\mathrm{T}_{4}: \mathrm{T}_{3}$ ratio recorded at different ages did not exhibit specific trend.
\end{abstract}

Keywords: Endocrine, growth, puberty, buffalo, thyroid stimulating hormone, triiodothyronine, thyroxine, calves, heifers.

\section{INTRODUCTION}

Of all the dairy animals, the Asian water buffalo holds the greatest promise and potential for production. Almost the entire world buffalo population is in the Asian subcontinent. India, China, Pakistan, Thailand and Indonesia are some of the major countries accounting for a large buffalo population. India has $57 \%$ of the world's buffalo population and $16 \%$ of the cattle population. It ranks first in respect of buffalo and cattle population. The production of buffalo milk in the Asian-Pacific region exceeds 45 million tones annually of which over 30 million tones is produced in India alone. Indian agriculture is an economic symbiosis of crop and livestock production. As India enters an era of economic reforms, agriculture, particularly the livestock sector is positioned to be a major growth area. It is increasingly recognized that dairying could play a more constructive role in promoting rural welfare and reducing poverty.

Buffalo, as the major livestock species for milk and meat production, contribute significantly to the economy of many countries in south and south-east Asia, South America, Africa and the Mediterranean. Improved buffalo production could significantly enhance the economy and the living standards of farmers in countries where buffaloes predominate,

${ }^{*}$ Address corresponding to this author at the Department of Veterinary Physiology, Bombay Veterinary College, Parel, Mumbai - 400 012, India; Tel: +91 9821097256; Fax: +9122 24172301;

E-mail: shaileshingole@hotmail.com particularly, in countries with a tropical climate. The major factors limiting the efficient utilization of buffaloes in countries with a tropical climate are : late maturity, poor estrus expressivities, long postpartum calving intervals, low reproductive efficiencies and fertility rates which are closely linked with environmental stress as well as managerial problems. As good reproductive performance is essential for efficient livestock production, the female buffalo calves must grow rapidly to attain sexual maturity, initiate estrous cycles, ovulate and be mated by fertile males or inseminated with quality semen to optimize conception and production. In the last two decades, considerable attention has been focused on understanding some of the causes for inherent limitations in reproduction among buffaloes by studying their reproductive endocrinology as well as developing biotechniques for augmenting their reproductive efficiency [1].

Growth is the basis of livestock enterprise and is thus of great economic importance. It is a complex phenomenon of physiology and nutrition and is determined by the genetic make up and its interaction with the environment. The rate of growth and the timing of sexual maturation are the two important factors, which directly affect the age at first calving. The period from birth to the age at first calving is essentially nonproductive and costly. Since early puberty is important to the overall animal's productive life span, the need is to reduce the age at puberty in buffalo heifers with optimal body weight attainment so that the nonproductive state can be transformed to the productive 
state as quickly as possible. Growth is the outcome of interactions among several factors, viz., genetic, nutritional, environmental and social factors, where the endocrine system plays the key role in co-ordination of all these interactions leading to the changing pattern of growth [2].

Buffalo are the mainstay of the milk production system in India amounting to about $54 \%$ of the total milk production. However, they suffer from slow growth rate and delayed puberty. In particular, Indian Murrah, an important dairy breed of buffalo, has been recorded to attain puberty at an age as high as 33 months. Puberty, the final maturation of the sexual phenotype, is the consequence of increased secretion of gonadal steroids, driven by increased production and secretion of gonadotrophins. Changes in the hypothalamichypophyseal-ovarian axis before puberty have been investigated in cattle and sheep [3]. Information on the endocrine mechanisms that regulate the onset of puberty in buffalo heifers is scarce. In particular, information is limited on the pattern of serum thyroid stimulating hormone, triiodothyronine and thyroxine concentrations in such animals.

However, the information on hormones in relation to growth in buffalo calves and heifers is not adequate. The present study was therefore proposed with the following objectives :1) to study the endocrine profile viz. thyroid stimulating hormone, tri-iodothyronine and thyroxine in female buffalo calves from birth to puberty and 2) to compare the endocrine profiles recorded at different stages of growth in female buffalo calves and heifers.

\section{MATERIALS AND METHODS}

The study was conducted on Murrah female buffalo calves and heifers, varying in age from newborn to 30 months, from Shri. Warana Sahakari Dudh Utpadak and Prakriya Sangh.Ltd., Warana Nagar, Kolhapur, were utilized used for the present in this study. In accordance with their age, the buffalo calves and heifers were divided into 14 groups, 12 in each as : birth to 7 days, 8 to 15 days, 16 days to 1 month, 1 to 2 months, 2 to 4 months, 4 to 6 months, 6 to 8 months, 8 to 10 months, 10 to 12 months, 12 to 15 months, 15 to 18 months, 18 to 21 months, 21 to 24 months and 24 to 30 months. The animals were maintained under standard conditions of feeding and management. The calves were allowed to suckle twice a day before milking. Milk Replacer was given to calves upto 4 - 6 months of age and then gradually shifted to Calf Starter containing rice bran without oil, rice polish, maize, rape seed cake, cotton seed cake, sunflower cake, groundnut cake, soyabean cake, molasses, mineral mixture, salt, lime stone powder, Berga (lipid source) and vitamin $A, D$ and $E$ up to $8-10$ months of age along with green roughages comprising of Napier grass and Lucerne grass. The animals from $10-12$ months of age was given $1-2 \mathrm{~kg}$ of kadba kutti as dry roughage along with $2-3 \mathrm{~kg}$ concentrate mixture, which was offered in two instalments i.e. in morning and evening, daily. The animals were supplied water ad libitum, twice a day, at 6.30 a.m. and 4.30 p.m. Deworming was done regularly and vaccination of dairy herds was carried out every year before the onset of monsoon against Heamorrhagic Septicemia. The Foot and Mouth disease vaccination was repeated every six months in all animals. The animals were housed in an open shed with an asbestos cement roof.

Blood samples (8 $-10 \mathrm{ml})$ were collected aseptically from the jugular vein in the separate sterile glass vials without anticoagulant. Samples were collected in morning hours between 8 a.m. and 10 a.m. after feeding. Serum was separated by centrifugation at $3000 \mathrm{rpm}$ for 15 minutes. The serum samples were stored at $-20^{\circ} \mathrm{C}$ until assayed.

The serum levels of thyroid stimulating hormone were estimated by radioimmunoassay using the classical double antibody technique [4] as modified by Midgley [5]. The antibodies, standard and hormones for radio-iodination of thyroid stimulating hormone were procured from Dr. A.F. Parlow, Pituitary Hormone and Antisera Centre, Harbor-Ucla Medical Centre, 1000 West Carson Street, Torrance, California, 90509 U.S.A. Sodium iodide $\left(\mathrm{Na}{ }^{125} \mathrm{I}\right)$ for protein iodination was obtained from Babha Atomic Research Centre, Mumbai.

\section{Radioimmunoassay (RIA) for Thyroid Stimulating Hormone (TSH)}

Bovine thyroid stimulating hormone antigen highly purified, for iodination, USDA-bTSH(AFP-8755B), approximately $128 \mu \mathrm{g} /$ ampoule, lyophilized, was reconstituted with $512 \mu \mathrm{l}$ of PBS and aliquots of $10 \mu \mathrm{l}$ were made and stored at $-70^{\circ} \mathrm{C}$. Each aliquot contained $2.5 \mu \mathrm{g}$ hormone for iodination and standard.

Bovine thyroid stimulating hormone antiserum (rabbit), NIDDK-anti-bTSH-AS(AFP-642482 Rb), 1:100 dilution lyophilized, in $2 \%$ normal rabbit serum (NRS) in phosphosaline buffer (PBS) was reconstituted by 
adding $1 \mathrm{ml}$ of distilled water to make $1: 100$ antiserum dilution.

\section{Assay Procedure for TSH}

To first two tubes only $100 \mu$ of labeled hormone was added (approximately 52,000 cpm). [Total count tubes]. To 3, 4 tubes $500 \mu \mathrm{l}$ of $0.1 \%$ gel PBS and 200 $\mu l$ of 1:400 NRS EDTA PBS were added [NSB tubes]. In tubes 5 and $6,500 \mu$ of assay buffer, i.e. $0.1 \% \mathrm{gel}$ PBS was added along with $200 \mu \mathrm{l}$ first antibody/antiserum was added [Zero binding tubes]. Cold hormones in different concentrations i.e. 10, 5, $2.5,1.25,0.625,0.3125,0.156,0.078,0.039$ and 0.019 ng of TSH per tubes were added, in assay tubes containing accordingly varying volumes of $0.1 \% \mathrm{gel}$ PBS making total of $500 \mu \mathrm{l}$ per tubes. Serum samples $300 \mu \mathrm{l}$ for TSH was added and volume was made up to $500 \mu \mathrm{l}$ with $0.1 \%$ gel PBS. Starting from fifth tube onwards $200 \mu \mathrm{l}$ of bTSH antiserum at dilution of $(1: 40,000)$ was added. To all tubes $100 \mu \mathrm{l}$ of ${ }^{125} \mathrm{I} \mathrm{bTSH}$ was added and kept for incubation for $24 \mathrm{~h}$ at room temperature. To precipitate bound fraction $200 \mu$ l of ARGG was added in all tubes (except total counts) and incubated for $24 \mathrm{~h}$ at $4^{\circ} \mathrm{C}$. The assay was terminated by adding $1 \mathrm{ml}$ of cold PBS (except total counts), $1 \mathrm{ml}$ of $5 \%$ PEG (polyethylene glycol) except total counts and centrifuging the tubes at $3000 \mathrm{rpm}$ for 35 minutes at $4^{\circ} \mathrm{C}$ in refrigerated centrifuge. Supernatant was carefully discarded, and the visible moisture was carefully wiped of by filter paper vicks. The bound fraction, which settled at the bottom of the tubes, was counted in RIA auto gamma counter. Standard graph was plotted by taking binding percentage on $\mathrm{X}$-axis and concentration on $\mathrm{Y}$-axis on log it log graph paper. Concentration of serum TSH was calculated on the basis of logit log graph paper for corresponding tube. Concentration per $\mathrm{ml}$ was calculated on the basis of corresponding tube hormone concentration reading. Inter and Intra assay variations were within the limits.

\section{Radioimmunoassay (RIA) for Triiodothyronine $\left(T_{3}\right)$ and Thyroxine $\left(\mathrm{T}_{4}\right)$}

The quantitation of $T_{3}$, and $T_{4}$, were done using RIA kits procured from Babha Atomic Research Centre, Mumbai.

\section{Assay Procedure for $T_{3}$}

The tubes for total counts, non specific binding (NSB), standards, controls and unknown were arranged and labeled. $400 \mu \mathrm{l}$ of assay buffer and $50 \mu \mathrm{l}$ free serum to NSB, $200 \mu \mathrm{l}$ of assay buffer and $50 \mu \mathrm{l}$ free serum to standards, $300 \mu \mathrm{l}$ of assay buffer and 50 $\mu \mathrm{l}$ free serum to zero standard and $300 \mu \mathrm{l}$ of assay buffer to controls or unknown was added to the appropriate tubes. $100 \mu \mathrm{l}$ of standard to respective standard tubes and $50 \mu \mathrm{l}$ of control serum to the respective control tubes were added. To all the tubes $100 \mu \mathrm{l}$ of ${ }^{125} \mathrm{I} \mathrm{T}_{3}$ was added. To all the tubes $100 \mu \mathrm{l}$ of antiserum complex was added except total count tubes and NSB tubes. The tubes were vortex and incubated for 45 minutes at $37^{\circ} \mathrm{C}$ or at room temperature for $3 \mathrm{~h}$. To all the tubes, $1 \mathrm{ml}$ of PEG was added except total count tubes. The tubes were mixed and centrifuged at $3000 \mathrm{rpm}$ for 20 minutes. The tubes were decanted except total count tubes and kept inverted on a blotting paper. Each tube was counted using a gamma counter for $1 \mathrm{~min}$.

\section{Assay Procedure for $\mathrm{T}_{4}$}

The tubes for total counts, non specific binding (NSB), standards, controls and unknown were arranged and labeled. $200 \mu \mathrm{l}$ of assay buffer to NSB and $100 \mu$ l of assay buffer to zero standard, controls or unknown to the appropriate tubes were added. $100 \mu \mathrm{l}$ of free serum to NSB, zero standard and standard tubes was added. $10 \mu \mathrm{l}$ of standard to respective standard tubes and $10 \mu \mathrm{l}$ of control serum to the respective control tubes were added. To the tubes 100 $\mu \mathrm{l}$ of ${ }^{125} \mathrm{I} \mathrm{T}_{4}$ was added. To all the tubes $100 \mu \mathrm{l}$ of antiserum complex was added except total count tubes and NSB tubes. The tubes were vortex and incubated for 30 minutes at $37^{\circ} \mathrm{C}$ or at room temperature for 75 minutes. To all the tubes $1 \mathrm{ml}$ of PEG was added except total count tubes. The tubes were mixed and centrifuged at $3000 \mathrm{rpm}$ for 20 minutes. The tubes were decanted except total count tubes and kept inverted on a blotting paper. Each tube was counted using a gamma counter for $1 \mathrm{~min}$.

\section{Statistical Analysis}

Analysis of variance of the data was done using Complete Randomized Design. Differences in means were tested using Critical Difference (CD) Test. To study the relationship of age, body weight and hormones, Correlation Coefficients were calculated [6].

\section{RESULTS AND DISCUSSION}

\section{Hormone Patterns from Birth to Puberty}

\section{Thyroid Stimulating Hormone}

The serum thyroid stimulating hormone profile is illustrated in Figure 1. The average values of serum 


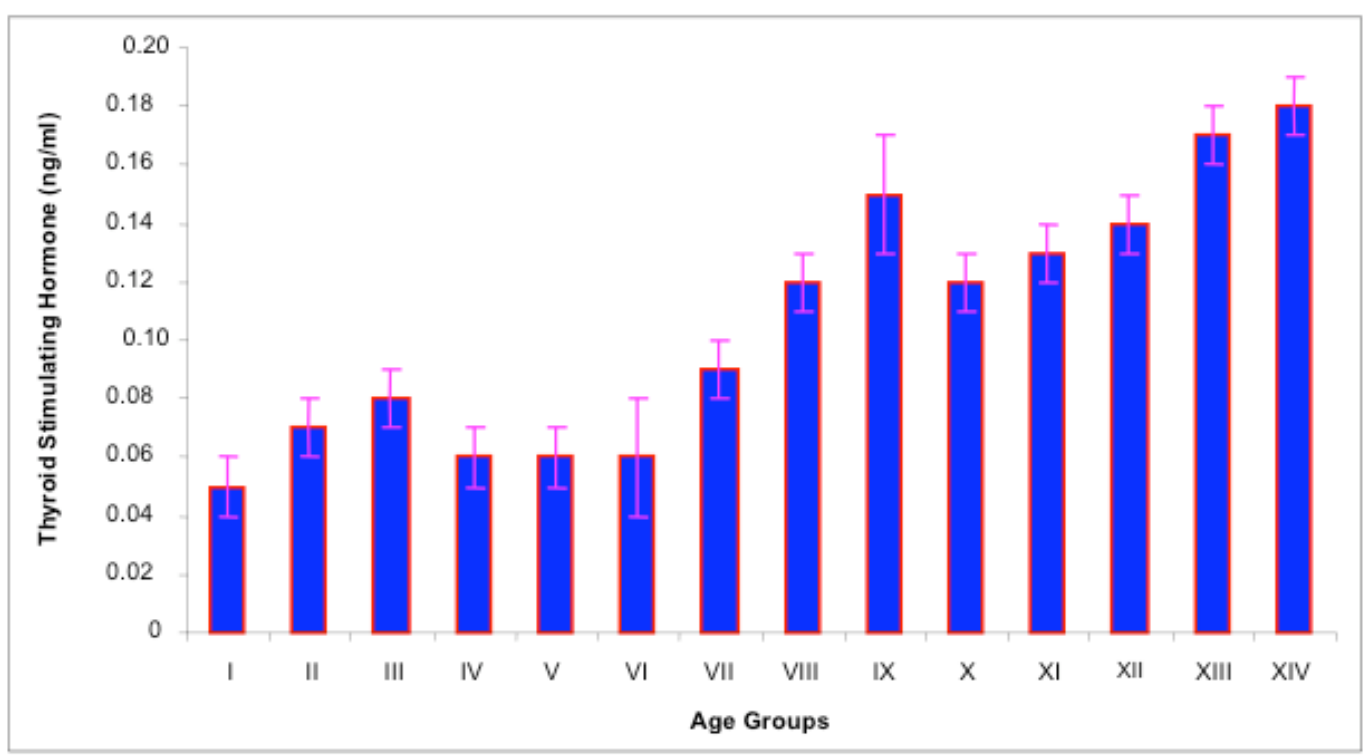

Figure 1: Profiles of serum thyroid stimulating hormone from birth to puberty in buffalo calves and heifers.

thyroid stimulating hormone concentration in buffalo calves were : $0.05 \pm 0.01,0.07 \pm 0.01,0.08 \pm 0.01$, $0.06 \pm 0.01,0.06 \pm 0.01,0.06 \pm 0.02,0.09 \pm 0.01,0.12$ $\pm 0.01,0.15 \pm 0.02,0.12 \pm 0.01,0.13 \pm 0.01,0.14 \pm$ $0.01,0.17 \pm 0.01$ and $0.18 \pm 0.01 \mathrm{ng} / \mathrm{ml}$ for $0-7$ days, 8 - 15 days, 16 days -1 month, $1-2$ months, $2-4$ months, $4-6$ months, $6-8$ months , $8-10$ months, $10-12$ months, $12-15$ months, $15-18$ months, $18-$ 21 months, 21 - 24 months, and $24-30$ months, respectively.

The thyroid stimulating hormone concentration did not differ and remained almost the same from birth to 4 - 6 months, of age in buffalo calves. The thyroid stimulating hormone concentration then gradually increased and reached a value of $0.18 \pm 0.01 \mathrm{ng} / \mathrm{ml}$, at $24-30$ months. The increases in thyroid stimulating hormone concentration recorded at $18-21$ months and $21-24$ months were statistically highly $(P<0.01)$ significant. The small increases in thyroid stimulating hormone concentration recorded at $6-8$ months, $8-$ 10 months, $12-15$ months and $15-18$ months, did not approach statistical significance. The thyroid stimulating hormone concentration recorded at $21-24$ months and $24-30$ months, i.e. at the age of attaining puberty, was about $3-4$ times higher than recorded at birth.

In the present study, the serum thyroid stimulating hormone concentrations from birth until reaching puberty were low. Jain et al. [7] reported almost negligible amount of thyroid stimulating hormone from birth to 91 days in buffalo calves and cow calves, using ELISA, and considered to be euthyroidic. The thyroid stimulating hormone concentrations recorded at puberty in the present study are in accordance with Bidye [8] in adult buffalo bulls and cow bulls. On another hand, Kesner et al. [9] showed no effect of thyrotrophin treatment in Holstein heifers but the values were high, while Leining et al. [10] irrespective of sex reported high concentrations in prepubertal bulls.

\section{Triiodothyronine}

The serum triiodothyronine profile is illustrated in Figure 2. The average values of serum triiodothyronine in buffalo calves were : $1.47 \pm 0.05,1.32 \pm 0.09,0.46 \pm$ $0.03,0.76 \pm 0.06,0.64 \pm 0.07,0.43 \pm 0.04,0.41 \pm 0.02$, $0.53 \pm 0.05,0.68 \pm 0.08,0.39 \pm 0.02,0.39 \pm 0.02,1.45$ $\pm 0.10,2.00 \pm 0.14$ and $1.58 \pm 0.16 \mathrm{ng} / \mathrm{ml}$ for $0-7$ days, 8 - 15 days, 16 days -1 month, $1-2$ months, 2 - 4 months, $4-6$ months, $6-8$ months , $8-10$ months, $10-12$ months, $12-15$ months, $15-18$ months, $18-21$ months, $21-24$ months, and $24-30$ months, respectively.

The triiodothyronine concentration recorded at $0-7$ days of age was significantly higher $(P<0.01)$ than those the concentrations recorded for other age groups except at $18-21$ months, $21-24$ months and $24-30$ months. The concentration of triiodothyronine decreased to a value of $1.32 \pm 0.09 \mathrm{ng} / \mathrm{ml}$ at $8-15$ days. The values further declined and reached to a lowest value of $0.39 \pm 0.02 \mathrm{ng} / \mathrm{ml}$ at $15-18$ months of age. The triiodothyronine concentration did not exhibit specific trend during the ages 16 days -1 month to 15 - 18 months. The triiodothyronine concentration recorded at $18-21$ monthsof age was almost 


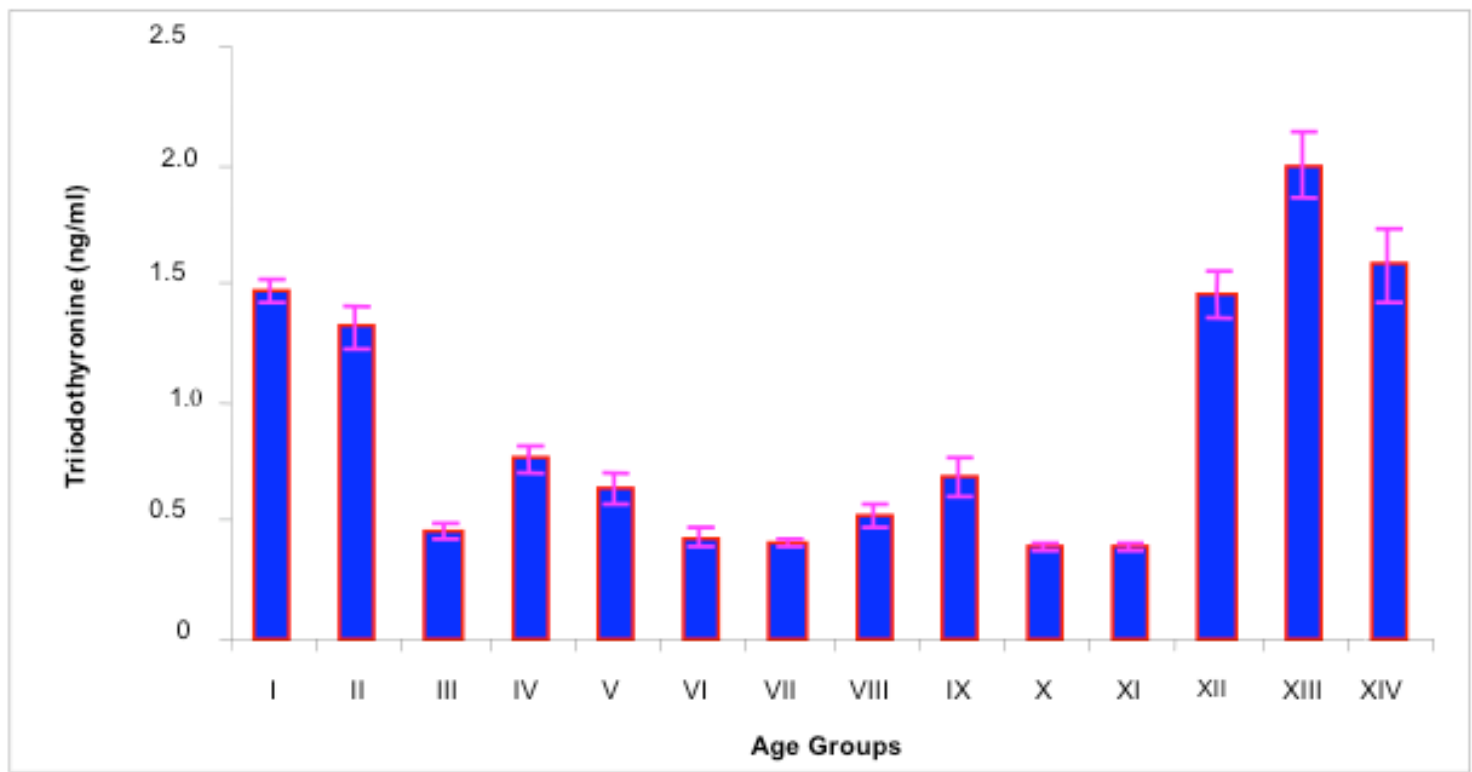

Figure 2: Profiles of serum triiodothyronine from birth to puberty in buffalo calves and heifers.

comparable to a value recorded at $0-7$ days. The highest triiodothyronine concentration was recorded at $21-24$ months followed by the concentration recorded at $24-30$ months and were statistically highly ( $P$ $<0.01)$ significant. The significant increase at birth and in the prepubertal and pubertal heifers i.e. at $21-24$ months and 24 - 30 months age, recorded in the present study is in agreement with Kumar and Rattan [11] in buffalo heifers. They opined that the high levels of triiodothyronine after birth in the young buffalo calves may be due to the phenomena of adaptation as in the period following birth. The calves remain under great stress for a considerable time immediately after birth as they face extra uterine environment which is further substantiated by the higher circulatory levels of cortisol. This extra uterine environment is more fluctuating than in-utero causing increased metabolic rate in order to adjust [12].

The higher concentration of triiodothyronine in $0-7$ days or newborn buffalo calves observed in the present study is in accordance with the reported findings in buffalo calves [13 - 15], cow calves [16, 17] and camel [18]. Contrary to these, an increasing trend in circulating levels of triiodothyronine was reported in buffalo calves from birth [19], while no significant high levels in plasma triiodothyronine levels after birth in Charolais calves was reported [20].

A sharp decrease in triiodothyronine concentration and increase by $16^{\text {th }}$ day was reported by Khurana and Madan [13], but the levels were higher after birth compared to the present study. This suggests that even at time of parturition there is great change in the thyroid functioning resulting in change in triiodothyronine. The higher triiodothyronine concentration observed at birth may be due to either increased thyroidal secretion or increased peripheral 5mono deiodinisation or due decreased triiodothyronine clearance. Even loss of placenta at birth removes a tissue which rapidly deiodinates triiodothyronine to further degraded products or removes it from circulation. The calves remain under stress for few hours after birth and the higher thyroid hormone levels may be one of the mechanisms to combat the stress by elevating basal metabolic rate. The high prepubertal level of triiodothyronine was recorded at $10-12$ months of age in the present study. Similar finding was reported by Sharma et al. [21] in male buffalo calves at $12-15$ months of age. These higher prepubertal (21 months onwards) levels of triiodothyronine recorded are necessary for enhanced synthesis of protein and gain in body weight.

The high triiodothyronine concentration after birth was also found in Surti buffalo calves [14]. The early neonatal stages maintain higher thyroid activity so that the required type of metabolic adjustments can be imposed. Pande et al. [18] recorded very high triiodothyronine values in camel calves as compared to other species, but with similar trend of gradual declining after birth. The higher levels of triiodothyronine after birth help the calves to adapt to extra uterine life. Under the influence of higher thyroid status the newborn mobilizes its resources to derive more energy which is possible due to high blood 
glucose levels and peak basal metabolic rate value at birth.

The highest concentration at $0-7$ days and then decreasing with advancing age in female Murrah buffalo calves is in accordance with Garg et al. [22]. They explained that the higher concentration of triiodothyronine in new born calves could be one of the adaptive mechanisms to overcome the stressful period after birth and subsequent declining trend could be attributed to the negative feed back mechanism exerted by already higher concentrations of triiodothyronine in blood. Besides, this increase in triiodothyronine secretion may also be due to higher thyroid stimulating hormone concentration or decreased triiodothyronine metabolic clearance due to low capability of triiodothyronine degrading enzymatic system in new born calves.

The concentrations of triiodothyronine recorded in the present study in pubertal heifers are in accordance with Surti buffalo heifers [23]. These levels in heifers may be due to influence of ovarian steroids. Thyroid hormones even though is governing basal metabolic rate, it has some positive association with ovarian activity and may reflect their importance in the reproductive physiology. In contrast, Leyva-Ocariz et al. [24] reported significantly decreased in triiodothyronine concentrations in pubertal Carora heifers, as this change could be critical to onset of puberty.

The prepartum cortisol surge increases hepatic renal and perirenal adipose tissue type I deiodinase and reduced renal and placental type III deiodinase activities. The increased availability of active triiodothyronine is important for latter phases of tissue differentiation. The functional development of brown adipose tissue allows to optimize non-shivering thermogenesis, thus permitting an adequate thermoregulation in the newborn. Therefore, uncoupling proteins (UPC) induced by the thyroid hormones, is of primary importance for the transition from foetal to neonatal life, when cellular energy and thermoregulatory requirements are at maximal rates. Besides, age related differences are evident during hot season [25].

\section{Thyroxine}

The serum thyroxine profile is illustrated in Figure 3. The average values of serum thyroxine in buffalo calves were : $74.24 \pm 4.29,41.74 \pm 5.69,29.98 \pm 1.91$, $28.34 \pm 2.04,39.85 \pm 4.36,37.55 \pm 1.78,39.16 \pm 2.65$,
$38.36 \pm 1.88,41.78 \pm 2.51,39.58 \pm 1.60,37.39 \pm 1.19$, $37.51 \pm 2.14,41.18 \pm 3.18$ and $40.76 \pm 2.00 \mathrm{ng} / \mathrm{ml}$ for 0 - 7 days, $8-15$ days, 16 days -1 month, $1-2$ months, $2-4$ months, $4-6$ months, $6-8$ months , 8 10 months, $10-12$ months, $12-15$ months, $15-18$ months, $18-21$ months, $21-24$ months, and $24-30$ months respectively.

The highest thyroxine concentration was recorded in $0-7$ days old buffalo calves. The thyroxine concentration decreased to a lowest value of $28.34 \pm$ $2.04 \mathrm{ng} / \mathrm{ml}$ at $1-2$ months age of buffalo calves. The decreases in the concentrations at these ages were statistically highly $(P<0.01)$ significant. The thyroxine concentration from $2-4$ months of age significantly increased and the values remained almost similar with minor fluctuations up to $24-30$ months and did not differ significantly through out growing period until puberty (birth to 30 months).

The decrease in thyroxine concentration with advancing age in buffalo calves is in accordance with Murrah buffalo calves [26]. The significantly higher level of thyroxine in early life is required for the adjustment to the external environment. Thyroxine is a calorigenic hormone and the thyroid activity is enhanced for maintaining constant body temperature by increasing the metabolic rate when exposed to cold environment. Therefore the level of thyroxine is high during first week of life.

The best known example of the effect of thyroid hormones on growth and development is the stimulation of precocious metamorphosis tadpoles. In animals, normal growth and development occur only in the presence of thyroid hormone, indicating that they play a permissive role in growth regulation. Since they are necessary for normal growth, thyroid hormones are classified as growth stimulators when present in optimal amounts [27].

The higher concentration of thyroxine at $0-7$ days observed in the present study is in agreement with the earlier reported findings in buffalo calves [15, 21, 22], cow calves [16, 17] and camel calves [18]. However, the values of serum thyroxine recorded were comparatively lower than that reported by these authors. The values of thyroxine recorded at $0-7$ days in the present study, are almost identical to that reported in cow calves [28]. Davicco et al. [20] observed no significant increase in thyroxine concentration after birth. A reduced metabolic clearance rate or an increased thyroidal secretion of 


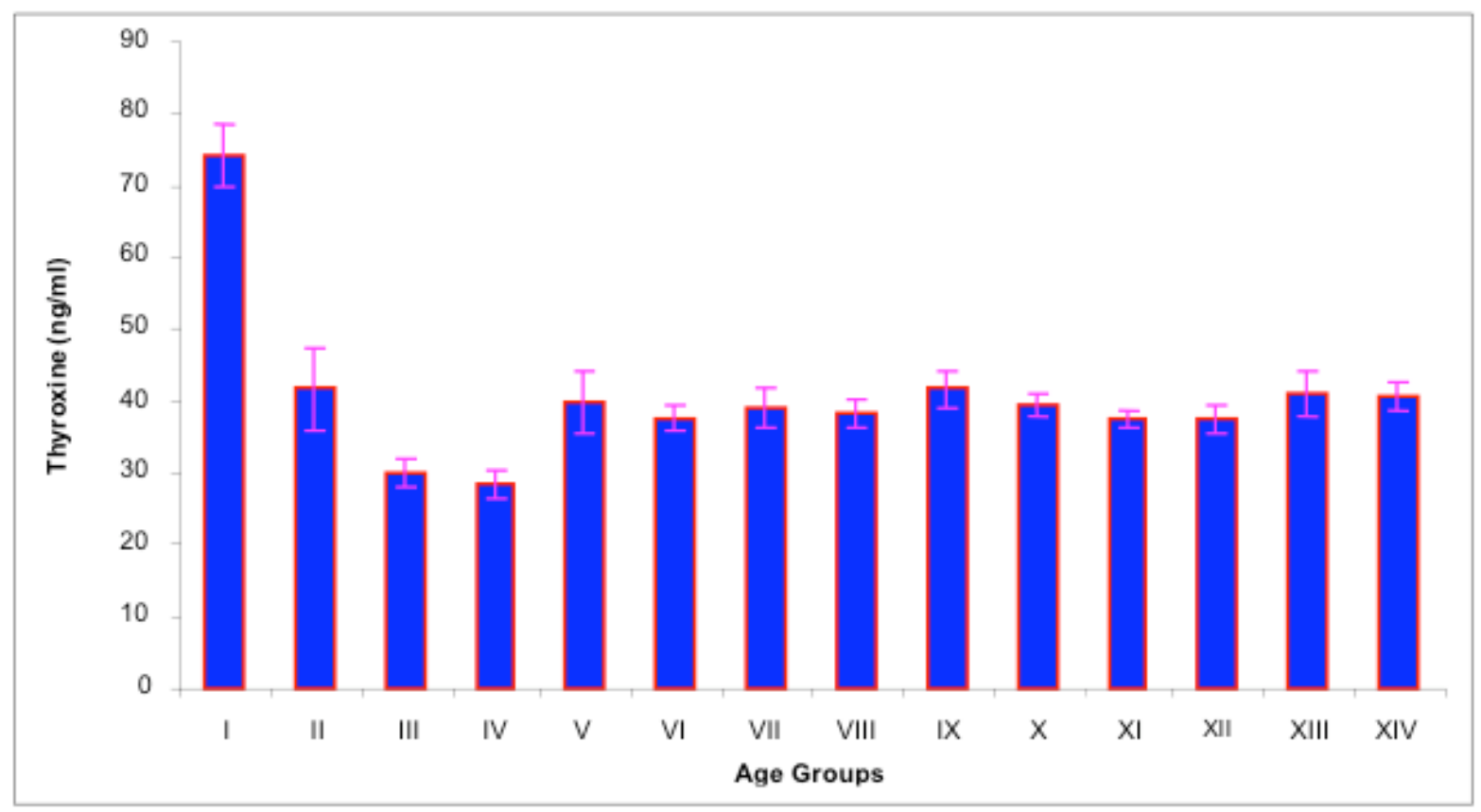

Figure 3: Profiles of serum thyroxine from birth to puberty in buffalo calves and heifers.

thyroxine in newborn may be a possible explanation for increased thyroxine concentration on first day of life. The required type of metabolic adjustments can be imposed, therefore in early neonatal stages higher thyroid activity is maintained [14]. Similar declining trend has also been reported in camel calves [18]. The higher levels help the calves to adapt to extra uterine life. Contrary to these Agarwal et al. [19] reported an increasing trend throughout growth and a peak thyroxine concentration at puberty in male buffalo calves. Similar to the present study Gray et al. [29] reported increase in thyroxine concentrations which is required precisely in regulated amounts for normal tissue growth process. Also the increase thyroxine levels have been proposed as one of the modes of action of estrogen to bring to cyclicity.

The decrease in thyroxine concentration after one week of birth and then corresponding fluctuations during growing period through out observed in the present study is in agreement with earlier findings in male buffalo calves [21], and in female buffalo calves $[11,15]$. Since the calf remains under stress for few hours after birth, the higher thyroxine levels may be one of the mechanisms to combat the stress by elevating BMR. The slight high levels of thyroxine during prepubertal stage as observed during $21-24$ months and $24-30$ months of age may be necessary for enhanced synthesis of protein and gain in weight [21]. Kumar and Rattan [11] opined that the high level after birth may be due to the phenomena of adaptation.
External environment is more fluctuating than in-utero causing increased metabolic rate in order to adjust.

The thyroxine concentrations observed in the present study in pre pubertal and pubertal heifers are in accordance with Sarvaiya and Pathak [23], which may be due to influence of ovarian steroids. Thyroid hormones even though is governing basal metabolic rate has some positive association with ovarian activity and may reflect their importance in the reproductive physiology.

The significantly higher concentrations of thyroxine observed in new born buffalo calves in the present study could be attributed to the higher thyroidal secretion rate in these animals to provide a defensive mechanism by the calf after birth by increasing metabolic rate [15]. Besides the decrease in thyroxine level after birth, when thyroid stimulating hormone levels were still elevated can be due to inability of thyroid gland to respond, in terms of thyroxine secretion, to a prolonged stimulation by thyroid stimulating hormone, probably because a depletion of hormonal stores in the gland occurs during the few minutes of life and is likely that thyroid gland can respond to other stimulating factors [25].

\section{$T_{4}: T_{3}$ Ratio}

The serum $T_{4}: T_{3}$ ratio profile is illustrated in Figure 4. The average values of $T_{4}: T_{3}$ ratio in buffalo calves were : $51.79 \pm 4.10,34.53 \pm 5.58,70.19 \pm 7.81,42.05$ 


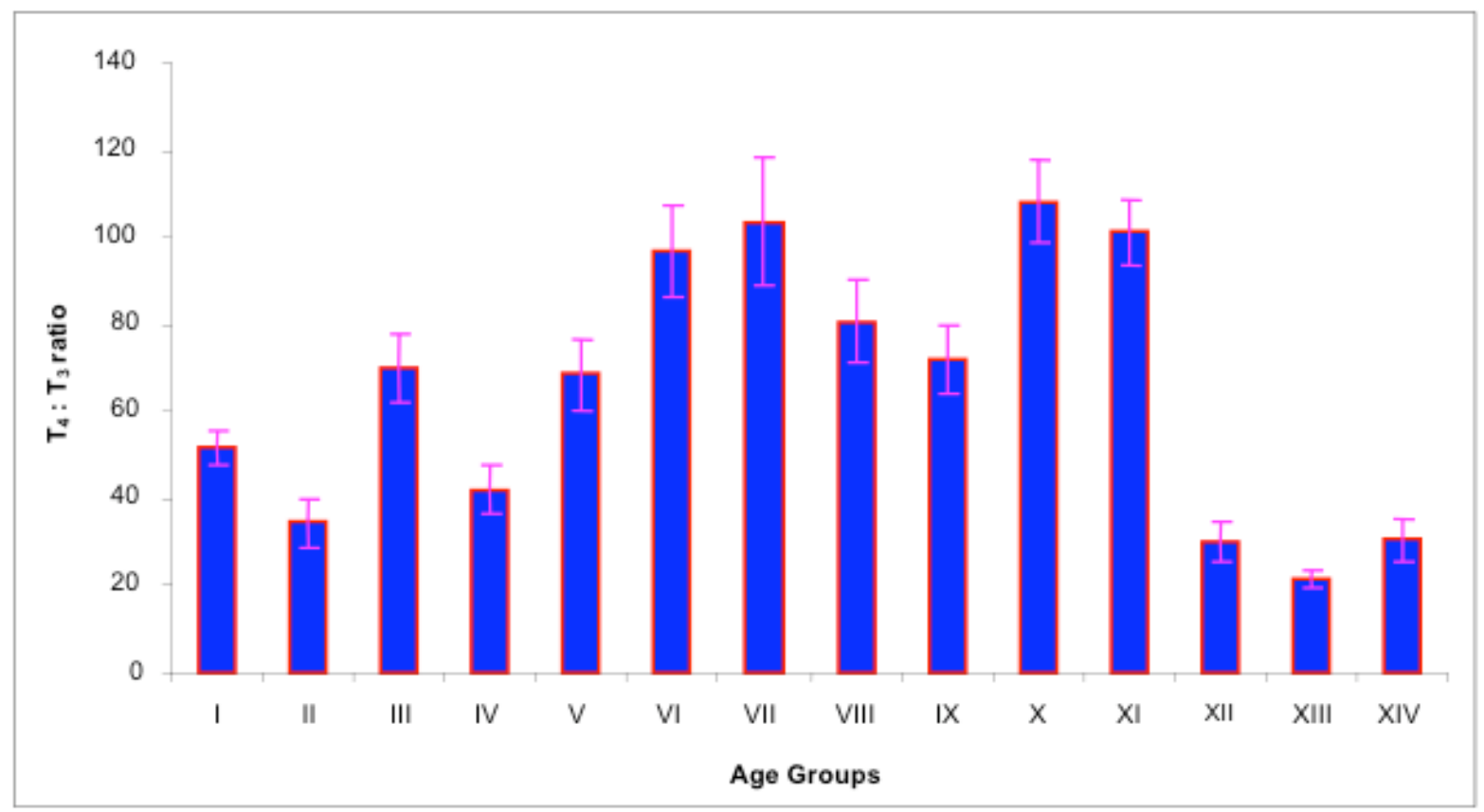

Figure 4: Profiles of $T_{4}: T_{3}$ ratio from birth to puberty in buffalo calves and heifers.

$\pm 5.56,68.37 \pm 8.26,96.92 \pm 10.52,103.67 \pm 14.82$, $80.76 \pm 9.36,72.13 \pm 7.90,108.22 \pm 9.70,101.19 \pm$ $7.47,30.22 \pm 4.71,21.73 \pm 2.07$ and $30.65 \pm 4.93$ for 0 - 7 days, 8 - 15 days, 16 days -1 month, 1 - 2 months, $2-4$ months, $4-6$ months, $6-8$ months , $8-$ 10 months, $10-12$ months, $12-15$ months, $15-18$ months, $18-21$ months, $21-24$ months, and $24-30$ months respectively.

The $T_{4}: T_{3}$ ratio recorded at $0-7$ days was higher than the $T_{4}: T_{3}$ ratio recorded at $8-15$ days, $1-2$ months, $18-21$ months, $21-24$ months and $24-30$ months. The differences among these $T_{4}: T_{3}$ ratios, except the one that recorded at $0-7$ days, were statistically non significant. Further, the $T_{4}: T_{3}$ ratios recorded at $4-6$ months, $6-8$ months. $8-10$ months, $12-15$ months and $15-18$ months were significantly higher than the $T_{4}: T_{3}$ ratio recorded at $0-$ 7 days. The highest $T_{4}: T_{3}$ ratio was recorded at $12-$ 15 months. The $T_{4}: T_{3}$ ratio recorded at $18-21$ months through $24-30$ months was almost half the ratio that recorded at $0-7$ days. The $T_{4}: T_{3}$ ratios recorded at different ages (birth to 30 months) did not exhibit specific trend.

The values of serum $T_{4}: T_{3}$ ratio recorded in the present study are comparatively higher than the $T_{4}: T_{3}$ ratio recorded in male buffalo calves [21]. In their study on serum thyroid hormone levels in male buffalo calves as related to age and sexual development they recorded higher $T_{4}: T_{3}$ ratio at $10-12$ months of age.
The values of serum $T_{4}: T_{3}$ ratio during $24-30$ months of age recorded in the present study are almost identical to that in Surti buffalo bulls, while lower than in Murrah, HF and Jersey bulls [8]. Agarwal et al. [19] however, reported more or less constant ratio from birth till maturity in male buffalo calves. Todini [25] attributed the high $T_{4}: T_{3}$ ratio to the effect of day length i.e. the long days. The present study was conducted during the month of June.

\section{Hormone Patterns in Relation to Body Weight}

Thyroid hormones directly influence growth by altering biochemical reactions, many of them influence size of specific tissues and organs. Thyroxine is generally considered to have a direct effect on whole body growth. These hormones affect body mass and dimensions primarily by altering skeletal and or nitrogen metabolism.

The body weights of experimental buffalo calves and heifers aged $0-7$ days to $24-30$ months, ranged from 27.5 to $361.4 \mathrm{~kg}$. Based on body weights, the buffalo calves and heifers were divided into four groups, having body weight as $27.5-100 \mathrm{~kg}, 101-$ $200 \mathrm{~kg}, 201-300 \mathrm{~kg}$ and $301-400 \mathrm{~kg}$.

\section{Thyroid Stimulating Hormone}

The average thyroid stimulating hormone concentration $(\mathrm{ng} / \mathrm{ml})$ in relation to body weight is presented in Table 1. The serum thyroid stimulating 
hormone concentration recorded at $27.5-100 \mathrm{~kg}$ body weight group was $0.06 \pm 0.00 \mathrm{ng} / \mathrm{ml}$. The thyroid stimulating hormone concentration then increased with increase in body weights. The increases in thyroid stimulating hormone concentration recorded at 201 $300 \mathrm{~kg}$ and $301-400 \mathrm{~kg}$ onwards were statistically significant $(P<0.05)$ when compared with the concentration recorded at $27.5-100 \mathrm{~kg}$ and $101-200$ $\mathrm{kg}$ body weights. But variations observed in thyroid stimulating hormone concentration between 27.5 - 100 $\mathrm{kg}$ and $101-200 \mathrm{~kg}$; and $201-300 \mathrm{~kg}$ and $301-400$ $\mathrm{kg}$ body weights, were statistically non significant.

The results of serum thyroid stimulating hormone concentration in relation to body weight in buffalo calves and heifers, recorded in the present study could not be compared as no previous report could be traced.

Table 1: Serum Thyroid Stimulating Hormone Profile $(\mathrm{ng} / \mathrm{ml})$ in Relation to Body Weight in Buffalo Calves and Heifers

\begin{tabular}{|c|c|}
\hline Body Weight $(\mathbf{k g})$ & Thyroid stimulating hormone $(\mathbf{n g} / \mathbf{m l})$ \\
\hline \hline $27.5-100$ & $0.06^{\mathrm{b}} \pm 0.00$ \\
\hline $101-200$ & $0.07^{\mathrm{b}} \pm 0.00$ \\
\hline $201-300$ & $0.13^{\mathrm{a}} \pm 0.00$ \\
\hline $301-400$ & $0.15^{\mathrm{a}} \pm 0.01$ \\
\hline
\end{tabular}

${ }^{\text {a.b }}$ Means in the same row with different superscripts differ $(P<0.05)$.

\section{Tri-lodothyronine}

The average $T_{3}$ concentration $(\mathrm{ng} / \mathrm{ml})$ in relation to body weight is presented in Table 2 . The serum $T_{3}$ concentration recorded at 27.5 - $100 \mathrm{~kg}$ through 301 $400 \mathrm{~kg}$ body weight groups did not show a specific trend in relation to body weights and did not significantly differ. Bobek et al. [29] reported in bull calves that body weight gain from 28 - 104 days of age was significantly correlated with $\mathrm{T}_{3}$ levels. Leyva-Ocariz et al. [26] reported positive correlation between body weight and $T_{3}$ levels in Carora heifers.

Table 2: Serum Tri-lodothyronine Profile $(\mathrm{ng} / \mathrm{ml})$ in Relation to Body Weight in Buffalo Calves and Heifers

\begin{tabular}{|c|c|}
\hline Body Weight $\mathbf{( k g )}$ & $\mathbf{T}_{\mathbf{3}}(\mathbf{n g} / \mathbf{m l})$ \\
\hline \hline $27.5-100$ & $0.93 \pm 0.19$ \\
\hline $101-200$ & $0.42 \pm 0.00$ \\
\hline $201-300$ & $0.53 \pm 0.08$ \\
\hline $301-400$ & $1.35 \pm 0.34$ \\
\hline
\end{tabular}

\section{Thyroxine}

The average $T_{4}$ concentration $(\mathrm{ng} / \mathrm{ml})$ in relation to body weight is presented in Table 3 . The serum $T_{4}$ concentration recorded at $27.5-100 \mathrm{~kg}$ through 301 $400 \mathrm{~kg}$ body weight groups did not significantly differ. Sharma et al. [15] reported positive relationship between circulatory levels of thyroid hormones and body weight during growth in prepubertal and pubertal heifers. Bobek et al. [29] reported in bull - calves that body weight gain from 28 - 104 days of age was significantly correlated with $\mathrm{T}_{4}$ levels. Gray et al. [30] reported relatively constant serum $\mathrm{T}_{4}$ concentrations in Zeranol implanted and non implanted bulls from 8.3 to 10.2 months, increase at 11.1 months and decrease at 15.7 months of age. They attributed these changes to seasonal changes (11.1 months in September, 14.8 months in January), although increasing weight may have affected $T_{4}$ concentrations. Thyroxine is required in precisely regulated amounts for normal tissue growth [31]; low levels interfere with normal growth processes. Increased $\mathrm{T}_{4}$ levels have been proposed as one of the modes of action of estrogen or Zeranol growth promotants [32].

Table 3: Serum Thyroxine Profile $(\mathrm{ng} / \mathrm{ml})$ in Relation to Body Weight in Buffalo Calves and Heifers

\begin{tabular}{|c|c|}
\hline Body Weight (kg) & $\mathrm{T}_{\mathbf{4}}$ (ng/ml) \\
\hline \hline $27.5-100$ & $42.83 \pm 8.30$ \\
\hline $101-200$ & $38.35 \pm 0.80$ \\
\hline $201-300$ & $39.94 \pm 0.99$ \\
\hline $301-400$ & $39.21 \pm 1.02$ \\
\hline
\end{tabular}

\section{$T_{4}: T_{3}$ Ratio}

The average serum $T_{4}: T_{3}$ ratio in relation to body weight is presented in Table 4. Higher serum $T_{4}: T_{3}$ ratios were recorded at $101-200 \mathrm{~kg}$ and $201-300 \mathrm{~kg}$ body weight groups when compared to the $T_{4}: T_{3}$ ratios recorded at $27.5-100 \mathrm{~kg}$ and $301-400 \mathrm{~kg}$ body weight groups, but were statistically non significant. The results of serum $T_{4}: T_{3}$ ratio in relation to body weight in buffalo calves and heifers, recorded in the present study could not be compared as no previous report could be traced.

\section{Relationships of Age, Body Weight and Hormones}

The intercorrelations matrix of age, body weight and serum hormones in buffalo calves and heifers were observed. The body weight was highly positively 
Table 4: Serum $T_{4}: T_{3}$ Ratio in Relation to Body Weight in Buffalo Calves and Heifers

\begin{tabular}{|c|c|}
\hline Body Weight (kg) & $\mathbf{T}_{\mathbf{4}}: \mathbf{T}_{\mathbf{3}}$ Ratio \\
\hline \hline $27.5-100$ & $53.39 \pm 7.06$ \\
\hline $101-200$ & $100.29 \pm 3.38$ \\
\hline $201-300$ & $87.04 \pm 10.89$ \\
\hline $301-400$ & $45.95 \pm 18.52$ \\
\hline
\end{tabular}

correlated with age of buffalo calves and heifers ( $r=$ $0.97, P \leq 0.01)$. The serum hormones thyroid stimulating hormone $(r=0.92, P \leq 0.01)$ and $T_{3}(r=0.41)$ were positively correlated with age. The relationship of $T_{3}$ with age however, was statistically non significant. Serum $T_{4}$ and $T_{4}: T_{3}$ ratio was negatively correlated with age. The relationships were statistically non significant. The observation of the present study that the serum $\mathrm{T}_{3}$ concentration was positively correlated with age is in agreement with reported observation in buffalo calves and heifers [21]. However non significant negative correlation of serum $\mathrm{T}_{3}$ with age was reported in buffalo calves [22] and in Rathi calves [16]. Jain et al. [7] also reported negative correlation of serum $T_{3}$ with age in buffalo calves upto 91 days. The serum $T_{4}$ concentration was negatively correlated with age, in the present study, is in agreement with reported observations in female Murrah buffalo calves [26] and male buffalo calves [21].

With regards to the relationship of hormones with body weight, in the present study, except serum $\mathrm{T}_{4}$ and $\mathrm{T}_{4}: \mathrm{T}_{3}$ ratio, the remaining hormones viz. thyroid stimulating hormone $(r=0.91, P \leq 0.01)$, and $T_{3}(r=$ 0.26 ) were positively correlated with body weight of buffalo calves and heifers. The serum $T_{4}(r=-0.19)$ and $T_{4}: T_{3}$ ratio $(r=-0.07)$, were negatively correlated with body weights. The relationships however, were statistically non significant. The observation of the present study that the serum $\mathrm{T}_{3}$ concentration was positively correlated with body weight, although non significantly, is in accordance with reported relationships in Carora heifers [24] and male buffalo calves [21]. The serum $T_{4}$ concentration was negatively correlated with body weight in the present study. These results corroborates with the earlier published reports [26], who also found that thyroxine was negatively correlated with growth rate $(r=-0.17)$. Hart et al. [33] and Dvorak et al. [34] also observed inverse relationship of thyroxine with live weight gain in lactating cows. Sharma et al. [21] reported that non significant positive correlation between $\mathrm{T}_{4}$ and body weight in male buffalo calves.

As regards the relationships amongst the hormones studied, the serum thyroid stimulating hormone was positively correlated with serum $T_{3}(r=0.37)$ and negatively correlated with $T_{4}(r=-0.14)$ and $T_{4}: T_{3}(r=$ -0.22). The relationships were statistically non signifycant. The serum $\mathrm{T}_{3}$ concentration was positively correlated with $T_{4}(r=0.40)$, but the relationships were statistically non significant. These results corroborate the earlier reports [21], who also observed that $T_{3}$ and $\mathrm{T}_{4}$ levels were positively correlated $(r=0.56)$ with each other, in male buffalo calves. The serum $\mathrm{T}_{3}$ concentration was highly significantly negatively correlated with $T_{4}: T_{3}(r=-0.89, P \leq 0.01)$, while the relationships of serum $\mathrm{T}_{4}$ was statistically non significant and negatively correlated with $T_{4}: T_{3}(r=-0.12)$.

Thus it can be concluded from the present study that the gradual increase in thyroid stimulating hormone from birth up to $24-30$ months of age is important for attainment of mature body weight, thus bringing the buffalo to cyclicity. The high levels of triiodothyronine and thyroxine at birth is necessary for the calf to get adapted to the external environment and to decrease the stress. Similarly during attainment of puberty at age 24 - 30months, the increased triiodothyronine and thyroxine concentrations shows its importance in reproductive physiology and its association with ovarian activity.

\section{REFERENCES}

[1] Madan ML, Prakash BS. Reproductive endocrinology. Reprod Fertil Suppl 2007; 64: 261-81.

[2] Prakash S. Application of exogenous. Abteilung Physiologie Lehrstuhl Fur Physiologie 2004. www.weihenstephan.de/fml/physio/sonstig/prakash.htm

[3] Haldar A, Prakash BS. Peripheral patterns. Endocr Res. 2005; 31 (4): 295-306. http://dx.doi.org/10.1080/07435800500422608

[4] Greenwood FC, Hunter M, Glover JS. The preparation of 131I - labeled human. Broche J 1963; 89: 114-23.

[5] Midgley AR Jr. Radioimmunoassay. Endocrinology 1966; 79: 10-18.

http://dx.doi.org/10.1210/endo-79-1-10

[6] Snedecor GW, Cochran WG. Statistical methods, 8th Edn Oxford and IBH Publishing Company, New Delhi 1998.

[7] Jain AK, Sharma IJ, Tripathi RK, Agrawal RG, Quadri MA Status of thyroid hormones and development of internal defense of neonatal buffalo calves and cow calves from precolostral feeding through 91 days. 2006 www.ibic.lib.ku.ac.th/e-bulletin/2006-73.htm-312k.

[8] Bidye SV. Concentrations of serum thyroxine, triiodothyronine and thyroid stimulating hormone in buffalo and cow bulls. M.V.Sc thesis submitted to Maharashtra Animal and Fishery Sciences University, Nagpur 2002. 
[9] Kesner JS, Convey EM, Davis SL. Bovine serum hormone. J Anim Sci 1977; 44(5): 784-90.

[10] Leining KB, Tucker HA, Kesner JS. Growth hormone. J Anim Sci 1980; 51(4): 932-42.

[11] Kumar R, Rattan PJS. Plasma thyroidal. Indian J Anim Sci 1992; 62(8): 747-8.

[12] Guyton AC. Textbook of Medical Physiology. $6^{\text {th }}$ ed. W. R. Sanuders Co: Philadelphia, London; 1981. Ch.76.

[13] Khurana ML, Madan ML. Circulating tri-iodothyronine. Indian J Anim Sci 1984; 54(4): 304-7.

[14] Pathak MM, Patel AV, Mehta VM. Estimation of serum thyroxine. Indian J Anim Sci 1989; 59(1): 53-5.

[15] Sharma S. Studies on hormonal and blood biochemical profile of female buffalo calves as function of age. M.V.Sc Thesis submitted to Haryana Agriculture University 1996.

[16] Kataria N, Kataria AK. Thyroid hormone. IJCS 2005; 1(2).

[17] Takahashi K, Takahashi E, Ducusin RJ, Tanabe S, Uzukaa Y, Sarashina T. Changes in serum. J Vet Med Sci 2001; 63(2): 175-8.

http://dx.doi.org/10.1292/jvms.63.175

[18] Pande AM, Agarwal SP, Rai AK, Khanna ND. Serum thyroid. Indian J Anim Reprod 2001; 22(2): 179-80.

[19] Agarwal SP, Agarwal VK, Singh N, Dwarakanath PK. Serum testosterone. Indian J Anim Sci 1983; 53(6): 609-11.

[20] Davicco MJ, Vigouroux E, Dardillat C, Barlet J P. Thyroxine, triiodothyronine. Reprod Nutr Dev 1982; 22(2): 355-62. http://dx.doi.org/10.1051/rnd:19820306

[21] Sharma IJ, Agarwal SP, Agarwal VK, Dwarakanath PK. Serum thyroid hormone. Theriogenology 1985; 24(5): 50917.

http://dx.doi.org/10.1016/0093-691X(85)90058-5
[22] Garg SL, Sharma S, Rose MK, Agarwal VK. Age associated. Indian J Anim Sci 2002; 72(7): 579-81.

[23] Sarvaiya NP, Pathak MM. Profiles of progesterone. Buffalo $\mathrm{J}$ 1992; 8(1): 23-30.

[24] Leyva-Ocariz H, Lucciola J, Puzzar S. Serum thyroid hormone. Theriogenology 1997; 48(1): 19-31. http://dx.doi.org/10.1016/S0093-691X(97)00200-8

[25] Todini, L. Thyroid hormones in small ruminants. Animal 2007; 1(7): 997-1008. http://dx.doi.org/10.1017/S1751731107000262

[26] Singh B, Chaudhary KC, Singh M. Plasma growth hormone. Buffalo J 1993; 1: 49-54.

[27] Hafez ESE, Dyer IA. Text book of Animal Growth and Nutrition. Philadelphia: Lea and Febiger 1969; p. 146.

[28] Mitin V, Mijic B, Matolek-Volvoda B, Mikulec K. Development of thyroid. Veterinarski Arhiv 1983; 53(3): 85-98.

[29] Bobek S, Kacinska M, Zapletal, P. Thyroxine and triiodothyronine. Zentralblatt-fur-Veterinarmedizin-A 1980; 27(9-10): 697-701.

[30] Gray DG, Unruh JA, Dikeman ME, Stevenson JS. Implanting young bulls. J Anim Sci 1986; 63: 747-56

[31] Beitz DC. Physiological and metabolic. J Anim Sci 1985 61(Suppl 2): 1 .

[32] Muir LA. Mode of action. J Anim Sci 1985; 61(Suppl 2): 154.

[33] Hart IC, Bines JA, Morant SV. Endocrine control. J Dairy Sci 1979; 62: 270-7. http://dx.doi.org/10.3168/jds.S0022-0302(79)83235-X

[34] Dvorak M, Naumannova M, Bursa I. The relationship of serum thyroxine. Acta Veterinaria 1986; 55: 11-21. 